\title{
THE ELECTRONICS INDUSTRY IN SOUTHERN CALIFORNIA: GROWTH AND SPATIAL DEVELOPMENT FROM 1945 TO 1989*
}

\author{
Allen J. Scott and Mark H. Drayse**
}

\section{Introduction}

In this paper we provide a broad empirical description of the growth and locational structure of the electronics industry in Southern California. The paper is a companion piece to a recent study of the aircraft and parts industry in the same region (Scott and Mattingly, 1989). Together, these two papers provide an empirical foundation for further investigations of the growth of high technology industry in Southern California. This growth has been especially stimulated by federal spending for defense purposes. The defense-oriented manufacturing complex that has evolved in the region in the post-War decades is locationally organized within a series of specialized industrial districts (or technopoles) scattered across the entire landscape. Within these technopoles we typically find bifurcated local labor markets and intense local interlinkage of individual manufacturing establishments forming a transactions-intensive system of production. For present purposes, Southern California is defined as the region stretching from Santa Barbara in the north to San Diego in the south, and encompassing the seven counties of Los Angeles, Orange, Riverside, San Bernardino, San Diego, Santa Barbara, and Ventura.

The paper now opens with a discussion of the origins of the electronics industry in Southern California in the immediate post-World War 2 years. The statistical and geographic record of change in the industry from the $1950 \mathrm{~s}$ to the present time is examined in detail, with special emphasis on the development of a series of suburban technopoles around Los Angeles. The specifications of a questionnaire survey of electronics manufacturers in Southern California are delineated, and the data collected in the survey are then used to carry out two main lines of investigation. One of these is focused (very briefly) on patterns of employment and local labor market activity, the other (more expansively) on the structure of inter-establishment linkages in the industry. The paper ends with a brief review of the dynamics of high technology industrial development in Southern California.

\footnotetext{
*This research was supported by the National Science Foundation under grant number SES 8812828 .

**Professor and doctoral candidate, respectively, Department of Geography, University of California, Los Angeles, CA.
}

\section{The Origins of the Electronics Industry in Southern California}

In the pre-World War 2 years, electronics manufacturing in Southern California was largely confined to a small radio industry in Los Angeles serving the local market. Unlike places such as Berlin, Boston, London, and New York where electrical engineering activities flourished at this time (cf. Hall and Preston, 1988), the Lost Angeles industry remained relatively underdeveloped. Nevertheless, there was in the 1920s and 1930s a growing aircraft industry in Los Angeles (and to a lesser extent in San Diego), and a fledgling missile industry that developed over the $1940 \mathrm{~s}$. These industries became the principal conduit through which the modern electronics industry was ushered into Southern California in the 1950s and 1960s.

Thus, it was the existence of key aircraft and missile manufacturers such as Aerojet-General, Convair, Douglas, Hughes, Lockheed, North American, and Northrop that provided the initial impetus for the development of the modern electronics industry in Southern California in the immediate post-War years. The industry was also initially boosted by the large-scale defense appropriations for the Korean War in the early 1950 s, which created a demand for aircraft and missiles incorporating newly-developed electronic guidance, navigation and communication systems. The concentration of defense expenditures in Southern California at this time was striking; of the $\$ 7$ billion of outstanding Air Force contracts in July 1951, $\$ 1.3$ billion (18.6\%) had been awarded to local firms (Aviation Week, 1951). The "weapons system" concept fostered by the Pentagon encouraged the growth of a multi-tiered production network in which the components of each particular defense program were produced by layers of subcontractors, including electronics firms. The requirements of managing complex weapons systems production involving numerous firms also encouraged the localization of electronicsestablishments inclose proximity to the prime contractors, thereby facilitating coordination of the entire production process.

There is a marked dearth of published information on the Southern Californian electronics industry in the postWar years, but industrial directories and company reports from the period suggest that among the important electron- 
ics firms in the region in the early 1950s were Bendix, Collins Radio, Garrett, Gilfillan Brothers, Hallamore Electronics, Hoffman Radio, Learcal, Litton, RamoWooldridge, and RCA Victor. Only three of these firms - Collins Radio, Hoffman Radio and Gilfillan Brothers - were already present in Los Angeles prior to World War 2 (when they had been engaged in radio manufacture). The rest represent post-War developments, indigenous to Southern California for the most part, though some of them (e.g. Bendix and RCA Victor) were branch plants established in the region by eastern firms seeking presumably to take advantage of the massive agglomeration economies that were now becoming available within the region. At the same time, the major aircraft manufacturers were also establishing internal electronics divisions in order to hold on to parts of the business that were otherwise being increasingly subcontracted out to independent electronics producers. Northrop was the first to move in this direction with its Anaheim Division, set up in 1951, to produce precision instruments for the military (and was the first major aerospace producer to locate in Orange County). In 1954, the Convair Division of General Dynamics began producing electronics in its Pomona establishment. North American formed its Autonetics Division in Downey the following year to produce automatic navigation and control equipment. In 1957 the Nortronics Division of Northrop was established to consolidate the firm's inertial guidance, flight controls and precision optics manufacturing activities. Lockheed formed the Lockheed Electronics Company in Los Angeles in 1960, and Douglas built its Space Development Center in Huntington Beach in 1962.

Of all the electronics manufacturers in Southern California in the post-War years, one of the most remarkable was the Hughes Aircraft Company, which brought together a concentration of engineering and scientific workers that in the late 1940s was among the largest and most talented in the country (Ramo, 1988). During World War 2, Hughes had been engaged in the production of aircraft parts and R\&D services in Culver City. In 1947, the firm received an Air Force contract to develop the Falcon air-to-air missile, and in the following year it won a further large contract to produce the APG-33 fire-control radar for use on the Lockheed F-94 aircraft (Hughes Aircraft Company, 1986). On these bases, the company established itself at the forefront of missile and avionics technology development, and between 1948 and 1953, its total employment rose from 750 to 16,000 . In 1953, Simon Ramo and Dean Wooldridge, who had both joined the firm 1946, left to form RamoWooldridge (later TRW) in Inglewood. Soon after its founding, RamoWooldridge was awarded the task of overall system management on the intercontinental ballistic missile program, involving managerial supervision of the activities of 220 major corporations throughout the United States (Mettler, 1982). Also in 1953, Tex Thornton left Hughes to take over Litton Industries and then proceeded to build the company into a major defense electronics contractor. In 1960, Henry Singleton in turn left Litton to form Teledyne. Today, these four firms alone - Hughes Aircraft, TRW, Litton, and Teledyne - account for a major share of U.S. defense electronics contracting.

As the electronics industry grew and prospered in the region, so too there developed a significant infrastructure of specialized subcontractors and components suppliers, and a rapidly expanding pool of skilled scientific and technical labor. A number of large R\&D establishments also made their appearance, adding greatly to the region's aggregate stock of agglomeration economies. In 1945, the Air Force set up the RAND Corporation in Santa Monica to perform research on airborne weapons systems. Then, in short order, the Santa Barbara Research Center was established in 1952, Ford Aeronutronics in 1953, the System Development Corporation (an offshoot from RAND) in 1956, and Aerospace (an outgrowth of RamoWooldridge's System Engineering Division), and the Hughes Malibu Research Center in 1960.

In 1951, Southern California had some 10,000 workers in the electronics industry, and by the mid-1950s this number had grown to 35,000 . The industry was now poised on the threshold of a remarkable era of growth fueled by lavish defense expenditures, and structured by underlying processes of local labor market formation, the social division of labor (and concomitant inter-establishment linkage formation), and the emergence of dense agglomerated technopoles. We now provide a detailed statistical and cartographic description of this growth.

\section{Growth and Change, From the Mid 1950s to the Late 1980s}

Out of the historical roots described above, there emerged after the mid-1950s one of the most dynamic electronics manufacturing complexes in the United States, with a multifaceted focus on (a) computers, (b) military and space communication equipment, and (c) a diversity of components from printed circuit boards to advanced semiconductor devices.

\section{The Statistical Record of Growth}

The electronics industry is here explicitly defined in terms of three official 3-digit SIC categories, namely, SIC 357 (office and computing machines), SIC 366 (communication equipment), and SIC 367 (electronic components and accessories). The latter definition admittedly leaves much to be desired. It fails to accommodate certain sorts 
of electronic equipment procedures (such as manufacturers of X-ray apparatus or measuring and controlling devices), and it includes a few subsectors that have little to do with electronics (such as mechanical business machines). That said, the three designated sectors represent the only set of SIC categories that are overwhelmingly focused on electronics, and for which reasonably long runs of data for all seven counties of Southern California can be obtained. On the basis of a rough estimate, moreover, the same sectors account for some $90 \%-95 \%$ of all electronics employment in the region, Southern California ranks as one of the major center of electronics production anywhere in the world.

Throughout the post-War period from the 1950s and the 1980s, the electronics industry of Southern California has grown continually in terms of employment and number of establishments, except for periodic downturns corresponding to economic recessions or cutbacks in federal defense spending. Table 1 shows the number of establishments and employment in the industry as a whole in Southern California from 1959 to 1986. Over this period of time, the definitions of the three SIC categories that make up the electronics industry for the purposes of this study remain internally consistent. The number of establishments grew from 316 to 1,796 over the designated time period, and total employment grew from 43,517 to 233,230. Rates of growth have tended to decrease somewhat in recent years by comparison with rates that prevailed in the 1950 s and 1960s, though even today overall expansion remains remarkably vigorous.

In Figure 1 this pattern of growth is broken down by sector. The industry's early growth in the 1950 s is based on the production of communication equipment (SIC366), followed by electronic components and accessories (SIC 367 ), and then, in the late 1960 s, by office and computing machines (SIC 357). Since the early 1970s, all three sectors have expanded rapidly more or less in parallel with one another. In combination with the aerospace industry they form a complex of productive activities comprising a core of large systems houses imbricated within a network of innumerable smaller specialized producers and subcontractors. Systems house manufacturing is especially strongly developed in the communication equipment sector, where outputs often consist of large-scale R\&D intensive one-ofa-kind or small-batch products for particular military or space programs.

\section{The Changing Spatial Pattern}

The industry's overall record of growth is superimposed upon a constantly changing locational structure, involving above all the steady decentralization of the industry from Los Angeles, and its locational recomposition within a series of technopoles in the outer cities of the region. Even so, as shown by Table 2, Los Angeles county remains the regional hub of the electronics industry, especially for SIC 366. Orange and San Diego counties come second and third in order. They are followed in turn by Ventura and Santa Barbara counties which are beginning to evince strong signs of new technopole formation. Riverside and San Bernardino counties have remained over the entire post-War period somewhat unreceptive to high technology industrial development, possibly because of their older and more traditional industrial base anchored in steel, metalworking, and machinery manufacture. However, this base has declined rapidly in recent years, and definite signs of new high technology industrial growth are now increasingly evident in these latter two counties. All of these shifting locational structures underlying the data laid out in Table 2 may be more clearly apprehended by reference to maps of individual establishments within the study region (Figures 2,3, and 4).

In 1956, as revealed by Figure 2, the electronics industry was largely confined to three major districts

Table 1

Number of establishments and total employment in the Southern Californian electronics industry (SIC 357, SIC 366, SIC 367)

\begin{tabular}{|c|c|c|c|c|}
\hline & \multicolumn{2}{|c|}{ Establishments } & \multicolumn{2}{|c|}{ Employment } \\
\hline & Total & Rate of Change & Total & Rate of Change \\
\hline 1959 & 316 & - & 43,517 & - \\
\hline 1968 & 640 & $102.5 \%$ & 125,006 & $187.3 \%$ \\
\hline 1977 & 1,116 & $74.4 \%$ & 138,422 & $10.7 \%$ \\
\hline 1986 & 1,796 & $60.9 \%$ & 233,230 & $68.5 \%$ \\
\hline
\end{tabular}

Source: US Department of Commerce, Bureau of the Census, County Business Patterns. The data shown represent aggregates for the seven counties of Southem Califomia. Occasionally, County Business Pattems suppresses data for particular sectors in particular counties; where this is the case, employment has been estimated from interval data provided by the source. 


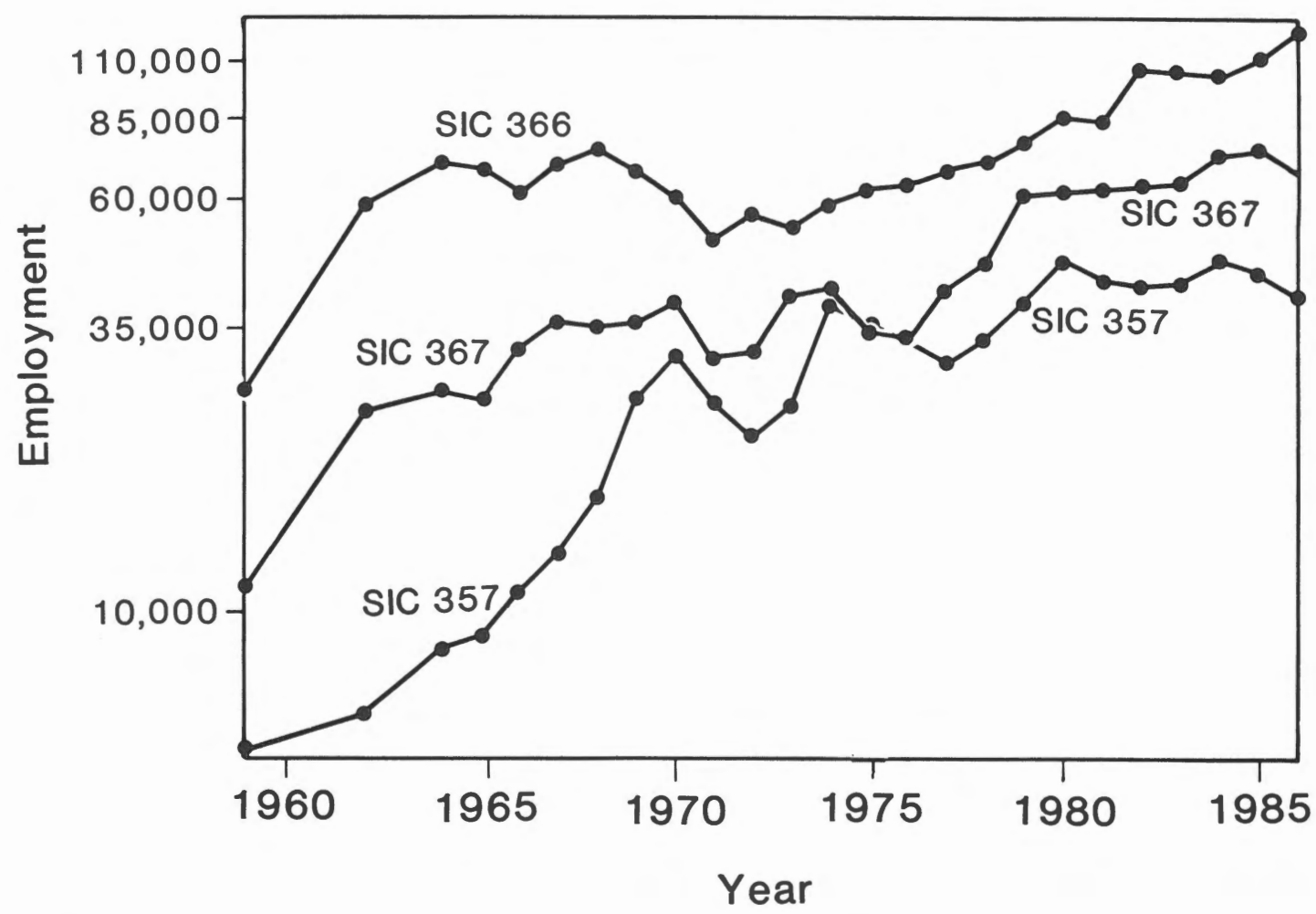

Figure 1. Employment in SIC 357 (office and computing machines), SIC 366 (communication equipment), and SIC 367 (electronic components and accessories) in Southern California from 1959 to 1986 . The vertical axis of the diagram is constructed on a logarithmic scale.

Source of data: US Department of Commerce, Bureau of the Census, County Business Patterns. The data shown represent aggregates for the seven counties of Southern Califomia. Occasionally, County Business Patterns suppresses data for particular sectors in particular counties; where this is the case, employment has been estimated from interval data provided by the source.

corresponding to the original locational base of the small pre-War radio industry to the west of the central business district of Los Angeles, together with two additional concentrations more or less corresponding to the early geography of the aircraft industry (cf. Scott and Mattingly, 1989). One of these districts lies to the west of the Los Angeles basin, stretching from Santa Monica in the north to El Segundo in the south; the other is situated in the BurbankGlendale-North Hollywood area in the eastern San Fernando Valley.

Figure 3 shows that by 1972 the electronics industry in the central area of Los Angeles was beginning to thin out, though the two technopoles of Santa Monica-El Segundo and Burbank-Glendale-North Hollywood are still at this time important centers of the industry. Also, three major technopoles in the outer cities of the region emerged over the 1960 s and early 1970 s. These correspond to (a) Orange County, and above all the area in and around Irvine (Scott, 1988), (b) the westward extension of the San Fernando
Valley cluster into Chatsworth-Canoga Park, and (c) the northern suburbs of San Diego where a small but very active electronics complex focused on components and computers was now forming.

Figure 4 shows the situation in 1988, which represents a continuation of the trends already noted in Figure 3. The thinning out of electronics establishments in the central area of Los Angeles continues, and is even evident in a small way in the two inner technopoles of Santa MonicaEl Segundo and Burbank-Glendale-North Hollywood. By contrast, the technopoles in Orange county, ChatsworthCanoga Park and San Diego have grown conspicuously in comparison with the pattern for 1972. There is also evidence of technopole formation in Santa Barbara and Ventura counties as well as in the Irvine Spectrum development to the southeast of the main Irvine technopole.

In functional terms the technopoles described above are focused upon a collection of large establishments locationally intertwined within a dense network of innu- 
Table 2

Number of establishments and employment in SIC 357 (office and computing machines), SIC 366 (communication equipment), and SIC 367 (electronic components and accessories) in Southern California, by county, 1959 - 1986.

\begin{tabular}{|c|c|c|c|c|c|c|c|c|}
\hline & \multicolumn{4}{|c|}{ Establishments } & \multicolumn{4}{|c|}{ Employment } \\
\hline & $\overline{1959}$ & 1968 & 1977 & $\overline{1986}$ & $\overline{1959}$ & 1968 & 1977 & $\overline{1986}$ \\
\hline \multicolumn{9}{|l|}{ Los Angeles: } \\
\hline SIC 357 & 40 & 53 & 94 & 151 & 4,410 & 13,986 & 11,970 & 13,143 \\
\hline SIC 366 & 62 & 152 & 200 & 201 & 18,407 & 29,350 & 37,831 & 60,584 \\
\hline SIC 367 & 179 & 263 & 321 & 445 & 10,023 & 25,072 & 18,212 & 28,700 \\
\hline Sub-totals & 281 & 468 & 615 & 797 & 32,840 & 68,408 & 67,913 & 102,427 \\
\hline \multicolumn{9}{|l|}{ Orange: } \\
\hline SIC 357 & 3 & 16 & 65 & 145 & 425 & 1,603 & 10,957 & 16,573 \\
\hline SIC 366 & 4 & 28 & 64 & 93 & 7,059 & 39,760 & 20,896 & 41,348 \\
\hline SIC 367 & 8 & 39 & 153 & 278 & 251 & 4,348 & 11,946 & 20,393 \\
\hline Sub-totals & 15 & 83 & 282 & 516 & 7,735 & 45,711 & 43,799 & 78,314 \\
\hline \multicolumn{9}{|l|}{ Riverside: } \\
\hline SIC 357 & 0 & 0 & 0 & 7 & 0 & 0 & 0 & 130 \\
\hline SIC 366 & 1 & 0 & 0 & 5 & 375 & 0 & 0 & 256 \\
\hline SIC 367 & 1 & 7 & 10 & 18 & 750 & 1,600 & 3,250 & 2,383 \\
\hline Sub-totals & 2 & 7 & 10 & 30 & $' 1,125$ & 1,600 & 3,250 & 2,769 \\
\hline \multicolumn{9}{|l|}{ San Bernardino: } \\
\hline SIC 357 & 0 & 0 & 0 & 14 & 0 & 0 & 0 & 1,259 \\
\hline SIC 366 & 0 & 0 & 3 & 5 & 0 & 0 & 358 & 175 \\
\hline SIC 367 & 0 & 0 & 13 & 35 & 0 & 0 & 122 & 664 \\
\hline Sub-totals & 0 & 0 & 16 & 54 & 0 & 0 & 480 & 2,098 \\
\hline \multicolumn{9}{|l|}{ San Diego: } \\
\hline SIC 357 & 2 & 5 & 19 & 58 & 750 & 1,150 & 4,467 & 6,262 \\
\hline SIC 366 & 7 & 18 & 50 & 71 & 435 & 3,183 & 6,144 & 14,106 \\
\hline SIC 367 & 0 & 25 & 38 & 132 & 0 & 2,211 & 5,399 & 9,379 \\
\hline Sub-totals & 9 & 38 & 107 & 261 & 1,185 & 6,544 & 16,010 & 29,747 \\
\hline \multicolumn{9}{|l|}{ Santa Barbara: } \\
\hline SIC 357 & 0 & 0 & 5 & 14 & 0 & 0 & 2,257 & 1,332 \\
\hline SIC 366 & 3 & 8 & 12 & 12 & 350 & 1,275 & 2,057 & 5,003 \\
\hline SIC 367 & 6 & 9 & 7 & 20 & 282 & 358 & 86 & 900 \\
\hline Sub-total & 9 & 17 & 24 & 46 & 632 & 1,633 & 4,400 & 7,225 \\
\hline \multicolumn{9}{|l|}{ Ventura: } \\
\hline SIC 357 & 0 & 0 & 3 & 17 & 0 & 0 & 125 & 1,392 \\
\hline SIC 366 & 0 & 0 & 6 & 11 & 0 & 0 & 449 & 4,494 \\
\hline SIC 367 & 0 & 5 & 22 & 64 & 0 & 1,200 & 1,996 & 4,754 \\
\hline Sub-total & 0 & 5 & 31 & 92 & 0 & 1,200 & 2,570 & 10,640 \\
\hline
\end{tabular}

Source: US Department of Commerce, Bureau of the Census, County Business Patterns. The data shown represent aggregates for the seven counties of Southern California. Occasionally, County Business Patterns suppresses data for particular sectors in particular counties; where this is the case, employment has been estimated from internal data provided by the source.

merable smaller producers (cf. Table 3). These large establishments form the core of the local defense electronics industry (see Figure 5) which when fans out through a hierarchy of smaller subcontractors and specialized input suppliers. The localized spatio-economic systems that have developed in the region in this manner function in large degree on the basis of an intricate structure of local labor market activity and short- and long-distance interestablishment linkages. We turn now to the specifications of a questionnaire survey of the industry, and, on the basis 


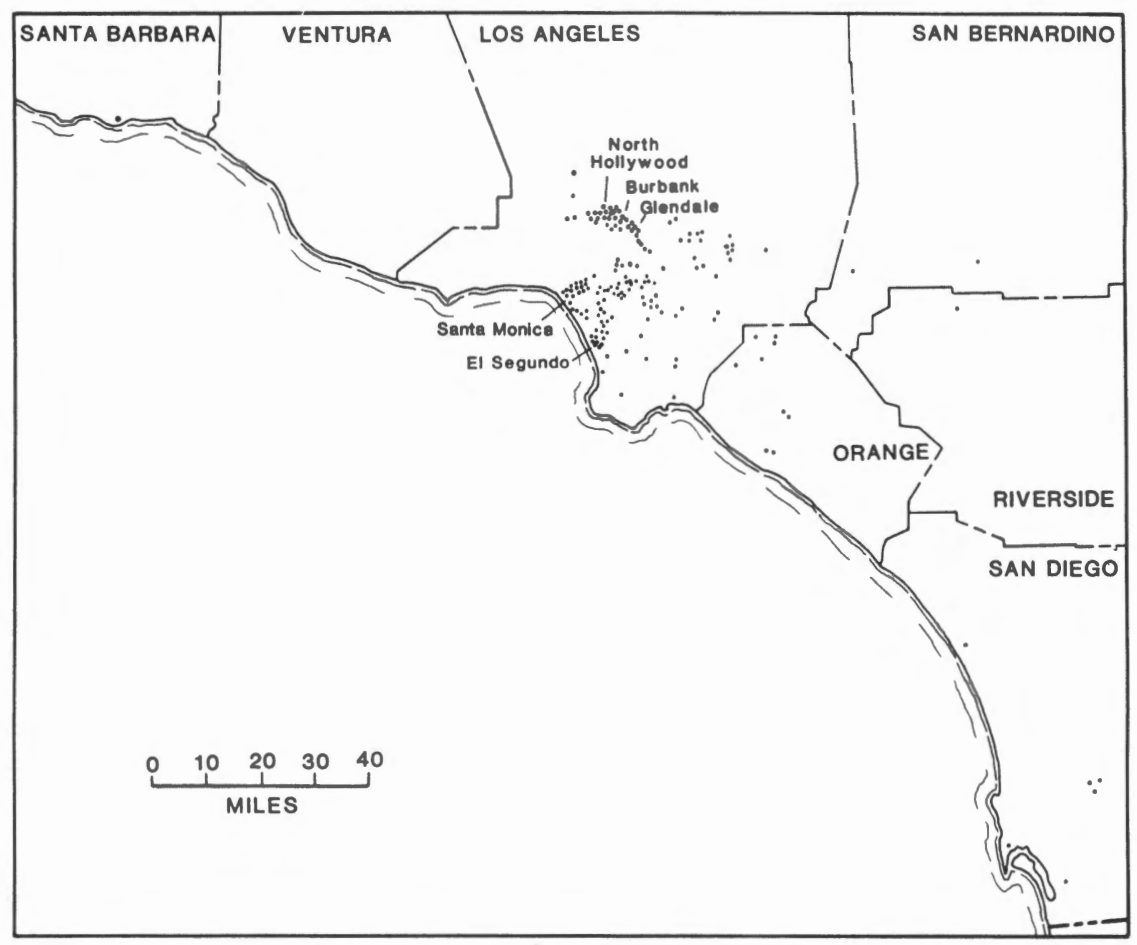

Figure 2. The electronics industry in Southern California, 1956. Each dot represents one establishment. Source of data: California Manufacturers Register, 1956.

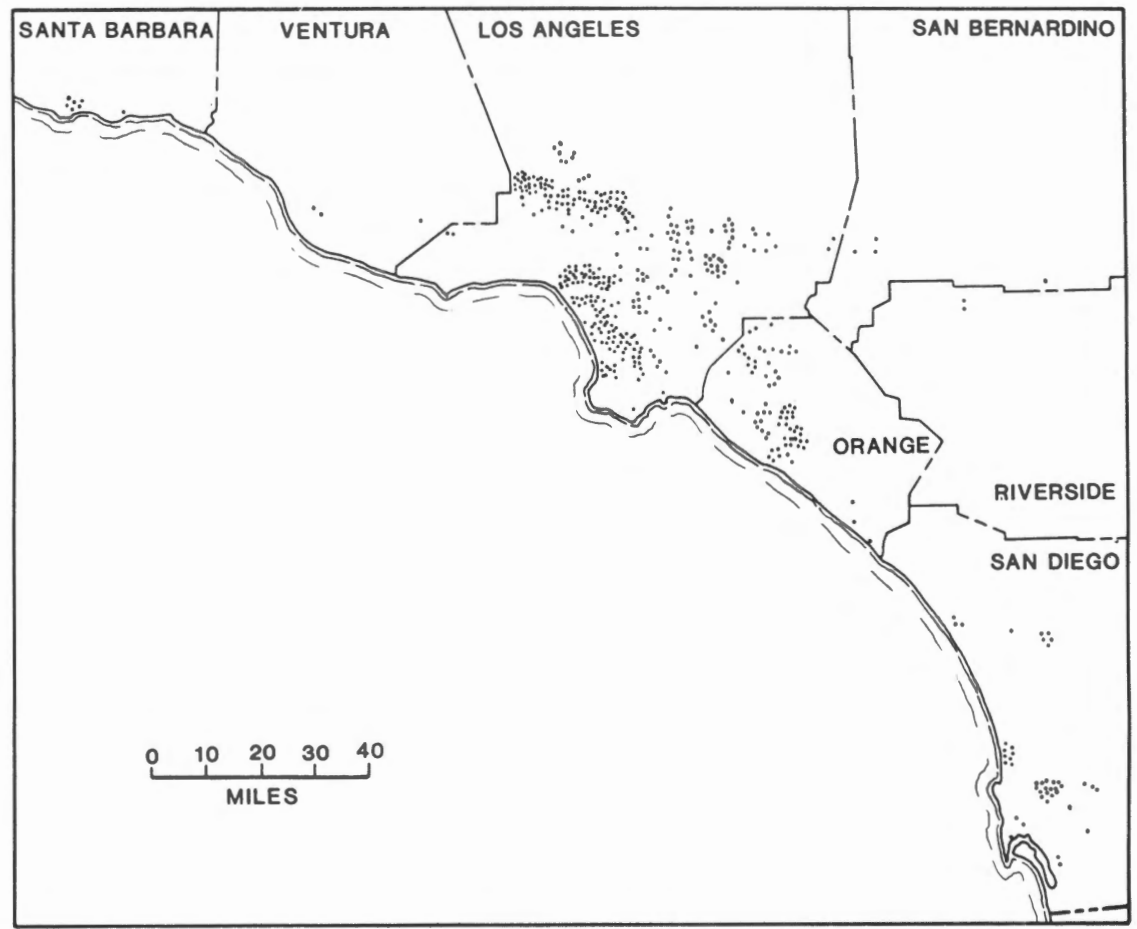

Figure 3. The electronics industry in Southern California, 1972. Each dot represents one establishment. Source of data: California Manufacturers Register, 1972. 


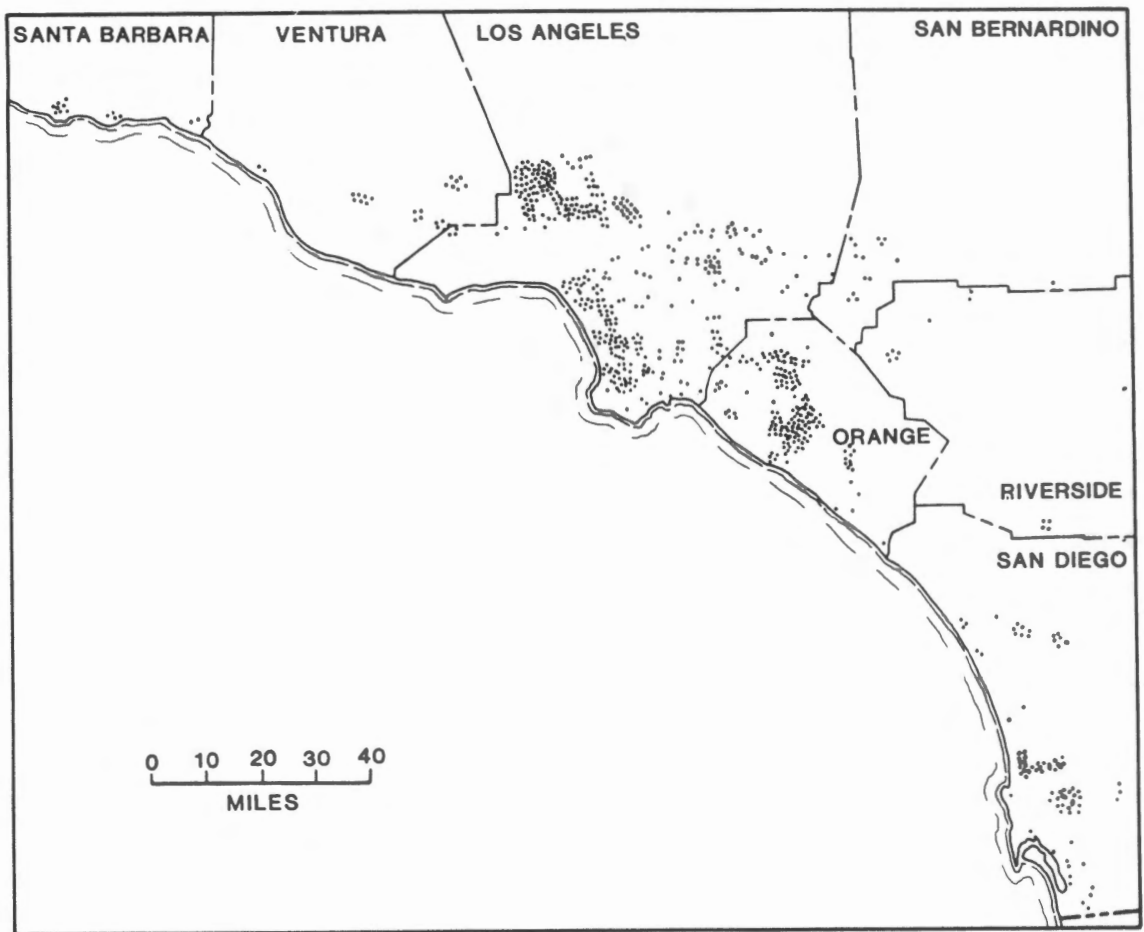

Figure 4. The electronics industry in Southern California, 1988. Each dot represents one establishment. Source of data: California Manufacturers Register, 1988.

Table 3

Size distribution of sample of electronics establishments compared with size distribution of the population of all electronics establishments in Southern California.

\begin{tabular}{|c|c|c|c|c|}
\hline \multirow{2}{*}{$\begin{array}{l}\text { Employment } \\
\text { size category }\end{array}$} & \multicolumn{2}{|c|}{$\begin{array}{c}\text { Sample establishments, } \\
1988 \\
\end{array}$} & \multicolumn{2}{|c|}{$\begin{array}{c}\text { Population of } \\
\text { establishments, } 1986\end{array}$} \\
\hline & Number & Percent & Number & Percent \\
\hline $1-4$ & 5 & 6.8 & 428 & 23.8 \\
\hline $5-9$ & 9 & 12.3 & 223 & 12.4 \\
\hline $10-19$ & 16 & 21.9 & 264 & 14.7 \\
\hline $20-49$ & 21 & 28.8 & 324 & 18.0 \\
\hline $50-99$ & 8 & 11.0 & 208 & 11.6 \\
\hline $100-249$ & 10 & 13.7 & 194 & 10.8 \\
\hline $250-499$ & 2 & 2.7 & 81 & 4.5 \\
\hline $500-999$ & 0 & 0. & 31 & 1.7 \\
\hline $1000+$ & 2 & 2.7 & 43 & 2.4 \\
\hline Totals & 73 & 100.0 & 1796 & 100.0 \\
\hline
\end{tabular}

Source of data for population: US Department of Commerce, Bureau of the Census, County Business Patterns. The data shown represent aggregates for SIC 357, SIC 366 and SIC 367, and the seven counties of Southern California. 


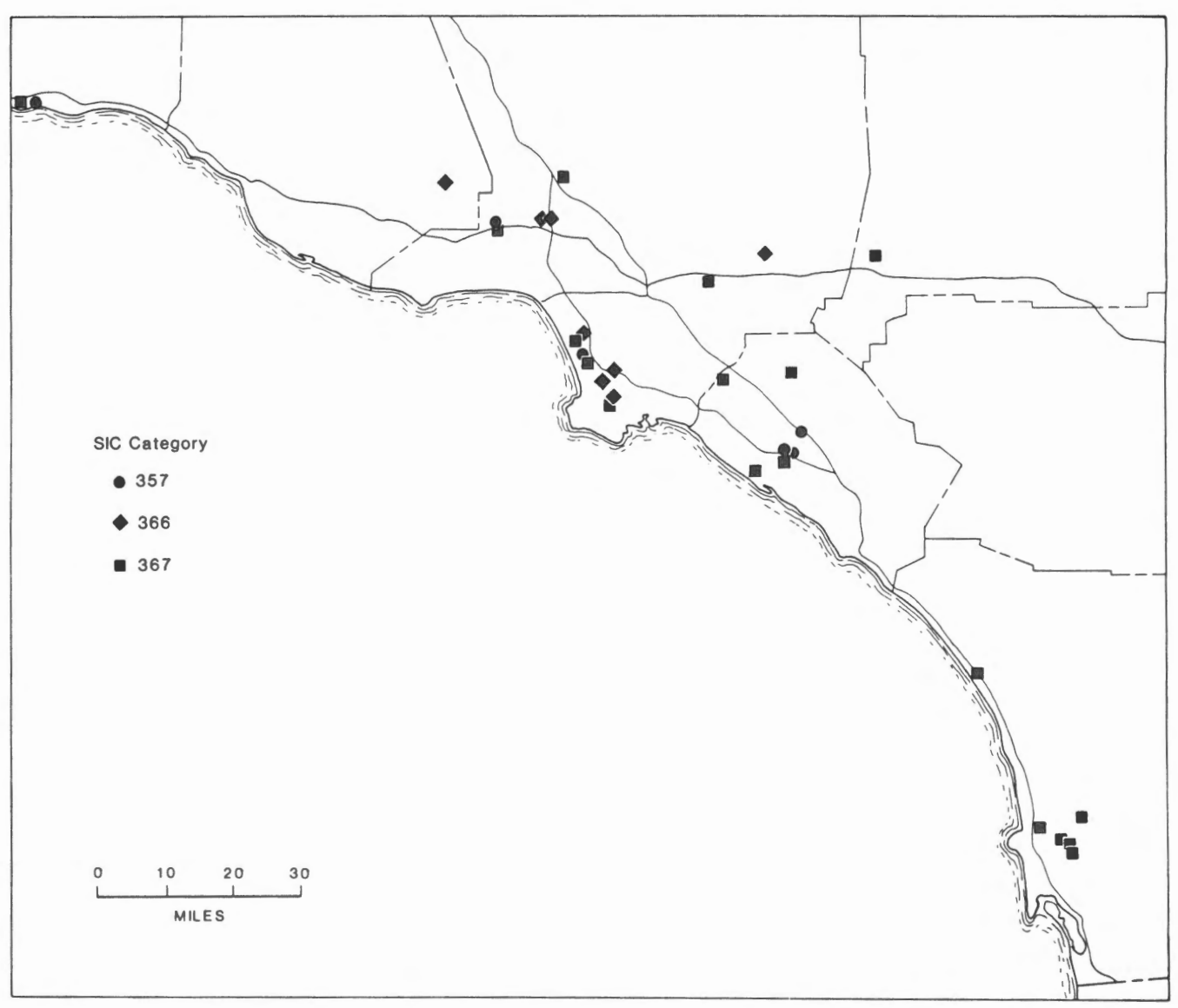

Figure 5. Large electronics manufacturing establishments in Southern California. Establishments shown all have 1,.000 or more employees. Source of data: California Manufacturers Register, 1989.

of the data collected in the survey, to an investigation of actual labor market and linkage structures in an effort to reveal the mainsprings of the peculiar locational pattern of the electronic industry of Southern California.

\section{Specifications of a Questionnaire Survey}

The analyses developed below are based upon data collected in a questionnaire survey of electronics manufacturers in Southern California carried out in late 1988 and early 1989. The questionnaire itself comprised four pages of detailed queries on such matters as production processes, outputs, sales volume, upstream and downstream linkages, subcontracting activities, and employment.

An attempt was made to send a questionnaire to all electronics producers in Southern California, including both single-establishment firms and the individual establishments of multi-establishment firms. The questionnaire was mailed to a total of 2,993 establishments gleaned from a variety of directories, but principally from the yellow pages telephone directories for the many different communities of Southern California. Out of the total set of questionnaires dispatched, a total of 100 were returned by respondents, of which however only 7.3 (i.e. $64.4 \%$ ) turned out to be bona fide electronics manufacturers. In addition, 290 questionnaires were returned by the Post Office as undeliverable. If we assume, then, that 2,703 questionnaires were actually delivered and that $66.4 \%$ of these represent genuine electronics manufacturing establishments (i.e. 1,795 individual cases - a figure very close to the number of establishments indicated for 1986 in Table 1), we have an effective response rate of $4.1 \%$. This is an unusually low response, even for this kind of survey, where response rates are more often in the general area of $10 \%-15 \%$ (Scott, 1988; Scott and Mattingly, 1989).

Part of the reason for the low rate no doubt lies in the circumstance that the questionnaire was not only long and complex, butalso asked for much proprietary information; part perhaps is due to the large numbers of very small establishments in the electronics industry, often run under sweatshop conditions, and owned by immigrant entrepreneurs. In fact, as suggested by Table 3 , the size distribution of sampled electronics manufacturers is significantly biased against small establishments in comparison to the 
corresponding distribution of all electronics manufacturers in the region. A Kolmogorov-Smirnov one sample test of the two distributions displayed in Table 3 indicates that they differ from one another at the 0.05 level of significance. Because of these manifest problems of the sample, the analysis that now follows must be treated with some circumspection. Nonetheless, the general results seem theoretically reasonable; they are also broadly consistent with the conclusion of other similar studies, and this raises confidence to some degree in their overall validity.

\section{Employment Structures}

At the present time the electronics industry of Southem California employs about a quarter-of-a-million workers, almost all of them in non-unionized establishments. According to the sample survey, $24.7 \%$ of the workers in the industry are engaged in managerial and R\&D occupations, and $55.4 \%$ are engaged in manual production work. Of the latter workers, more than half are members of minority ethnic or racial groups (Table 4). At the same time, $43.7 \%$ of all production workers are female. These simple data suggest at once that local labor markets in the Southern Californian electronics industry tend to be split into rather distinctive upper and lower tiers with the lower tier formed dominantly by immigrants and women.

Over the last few decades large numbers of immigrants (often undocumented) have moved steadily into the Southern Californian electronics industry, and they now perform the majority of all assembly and fabrication work (cf. Fernandez Kelly, 1987). As shown by Table 4, Hispanics represent the largest ethnic group in the industry, with $29.3 \%$ of production worker jobs among sample establishments on a simple average basis. Asians (particularly Vietnamese) form the next major group, with $18.4 \%$ of production worker jobs, and this group is now expanding at a particularly rapid rate. Blacks constitute only a small minority (3.6\%) of production workers. Observe that on a weighted average basis the percentage of Hispanics among production workers falls to $22.8 \%$ and the percentage of blacks rises to $10.4 \%$, signifying that
Hispanics are proportionally over-represented in small establishments and blacks in large. This finding may possibly be an outcome of a certain preference by small employers for illegal immigrants (among whom Hispanics) thus displacing many blacks except in the large establishment segment of the industry where greater concern for legality and affirmative action programs is more likely to prevail. In an earlier study (Scott and Paul, 1989) it was found that blacks are being denied equal access to jobs throughout the manufacturing economy of Southern California and its was argued that this state of affairs can be in significant degree ascribed to the squeezing out of blacks from local labor markets as a consequence of the largescale immigration of cheap labor.

Two additional significantitems of information were revealed by the questionnaire survey. One is that levels of part-time and temporary employment in the electronics industry are very small - contrary to expectations - for an average only $2.9 \%$ of all production workers at sample establishments are involved in part-time work, and only $3.0 \%$ are involved in temporary work. The other is that labor turnover among production workers is on the whole, and as expected, extremely high. Lay off and recall rates in excess of $25 \%$ a year are recorded respectively for $39.7 \%$ and $49.2 \%$ of sample establishments; and rates in excess of $50 \%$ are recorded respectively for $17.5 \%$ and $31.7 \%$ of establishments. These data reveal that there is a rapid rotation of production workers through the local job system. As Angel (1989) has suggested in a study of the semiconductor industry in Silicon Valley, high levels of turnover may also be expected to occur for many classes of scientific and technical workers in high technology industrial districts. The phenomenon of high turnover accentuates locational agglomeration by placing a premium on information and accessibility to alternative employment opportunities. The agglomeration economies of the region are yet further enhanced by the large local pools of habituated and socially-differentiated workers in both upper and lower labor market segments.

It is hoped in a further study to deepen and extend these remarks upon employment structures in the Southern

Table 4

Ethnicity, race and gender in employment patterns among sample electronics establishments $(n=62)$.

\begin{tabular}{lcc}
\hline & \multicolumn{2}{c}{ Percentage of production workers } \\
& Simple Average & Weighted Average \\
\hline Asians & 18.4 & 18.1 \\
Hispanics & 29.3 & 22.8 \\
Blacks & 3.6 & 10.4 \\
Females & 43.7 & 41.1 \\
\hline \hline
\end{tabular}


Californian electronics industry, and in particular, to carry out an in-depth investigation of the interrelations between production processes, employment, commuting, and location. In the absence of adequate information on individual workers' characteristics, these issues must be left for the moment in abeyance. We turn now to a study of interestablishment linkages, for which copious amounts of data were collected in the questionnaire survey.

\section{The Logic of Inter-Establishment Linkages}

\section{General Patterns of Purchases and Sales}

One of the objectives of the questionnaire survey was to discover to what degree electronics establishments in Southern California are linked to the local economy, and to what degree they are linked to a geographically wider circle of input providers and customers. With this objective in mind we asked respondents to tell us (a) what percentages of their total purchases come from within 15 miles of their establishment, and what from within Southern California as a whole, and (b) what percentages of their total customers are located within the same two spatial ranges. A summary of the results of this query is displayed in Tables 5 and 6. Both tables have been constructed by first of all grouping respondents into one of two size categories and then averaging the results over each category, where the dividing line between categories is defined as the median value (i.e. $\$ 2,000,000$ ) of the annual sales volume of all establishments providing information used in calculating the average percentages.

These two tables indicate that both small and large establishments are strongly linked in their upstream and downstream transactions to the local economy, though there are three important nuances to this judgment that need to be expressed. First, electronics establishments in Southern California do approximately one-third to twothirds on average of their business with other firms in the same region; and they do significant amounts of business even with firms located within a narrowly-defined circle of 15 miles radius from their own locations. Second, as was observed in the companion piece to the present paper (Scott and Mattingly, 1989), small establishments have more localized linkages than large, and in the case of sales linkages this discrepancy between the two groups is statistically significant at the 0.05 level by a test of the difference of means. Third, the pattern of purchases seems in general to be more spatially limited than the pattern of sales, though the differing measurements of these two variables make it necessary to append reservations to this remark. Oakey (1984) has noted parallel contrasts between the purchasing and sales patterns of high technology firms in other regional contexts. Notwithstanding these differences between the upstream and downstream linkage structures of sample establishments, the correlation coefficients laid out in Table 7 indicate that when an establishment has strong backward linkages to the local economy, it is likely also to have strong forward linkages. In addition, we find a simple correlation of 0.33 between (a) the percentage of any establishment's purchases that come from its top three suppliers and (b) the percentage of the same establishment's sales that go to its top three customers. For 39 sample observations this correlation is moderately significant at the 0.05 level. This observed relationship suggests that when an establishment's purchases are spread out over a large number of suppliers, its sales are likely to be similarly spread out; and when its purchases are concentrated on only a few suppliers, so too will its sales pattern be concentrated. Thus, when establishments are locked through their linkages into local agglomeration economies, they are typically bound in both upstream and downstream directions.

One common and very important form of interestablishment linkage in the electronics industry of Southern California involves subcontracting activity in the form of the putting out and taking on of work. On average, sample establishments put out work whose value amounts to $15.4 \%$ of total sales, and they take on work whose value is of the order of $20.2 \%$ of sales. In the questionnaire survey we asked respondents to specify the individual locations of the top three subcontractors to whom they put out work. Figure 6 and Table 8 summarize the responses that were received to this question. Figure 6 portrays the close locational symbiosis that exists between many electronics producers and their main subcontracting partners. Table 8 confirms this tendency by indicating that

Table 5

Average percent of total purchases by value originating (a) within 15 miles of respondent, and (b) within Southern California.

\begin{tabular}{|c|c|c|c|c|}
\hline & \multicolumn{4}{|c|}{ Establishment size (annual sales) } \\
\hline & \multicolumn{2}{|c|}{$<\$ 2$ million } & \multicolumn{2}{|c|}{$>\$ 2$ million } \\
\hline & $\overline{\%}$ & $\bar{n}$ & $\%$ & $\mathbf{n}$ \\
\hline Within 15 miles & 25.3 & 36 & 18.4 & 30 \\
\hline Within Southern California & 58.6 & 36 & 58.0 & 32 \\
\hline
\end{tabular}


Table 6

Average percent of all customers located (a) within 15 miles of respondent, and (b) within Southern California

\begin{tabular}{|c|c|c|c|c|}
\hline & \multicolumn{4}{|c|}{ Establishment size (annual sales) } \\
\hline & \multicolumn{2}{|c|}{$<\$ 2$ million } & \multicolumn{2}{|c|}{$>\$ 2$ million } \\
\hline & $\overline{\%}$ & n & $\%$ & $\bar{n}$ \\
\hline Within 15 miles & 21.2 & 37 & 8.6 & 32 \\
\hline Within Southern California & 46.8 & 37 & 31.6 & 32 \\
\hline
\end{tabular}

both small and large sample establishments overwhelmingly choose their major subcontract partners from the local area. Large establishments have a somewhat lower propensity to use local subcontractors than small, but there is no statistically significant difference between the two groups of establishments in this regard.

\section{Modes of Transacting}

In the questionnaire survey we sought to complement the data gathered on linkage structures with additional information on modes of transacting business. Specifically, we asked respondents to indicate the percentage of time allocated to differentmodes of transacting in the negotiations leading up to the sale of both a standard catalog item and a piece of subcontract work. The modes specified were telephone, face-to-face contact, mail, telex/fax, and other. Table 9 provides simple and weighted averages of responses to this question, where the weighted averages are computed in relation to the total sales volume of each establishment.

The data set out in Table 9 reveal that telephone and face-to-face contact are by far the most common modes of transacting for both catalog item sales and subcontract sales. The telephone dominates for catalog item sales, but face-to-face contact becomes just as important, if not more so, when the sale of subcontract work is at stake. As subcontracting usually involves considerable discussion between both parties about design specifications, materials, and ways of proceeding, it is not surprising that a particularly transactions-intensive mode of communication is generally resorted to in this instance. It is worthy of note that the weighted average allocation of time to faceto-face contact for the sale of subcontract work is distinctly larger than the corresponding simple average, which suggests that large electronics producers tend to have more transactions-intensive subcontract relations than small. Mail, telex/fax, and other modes of communication are evidently of much less significance in terms of time allocation than the telephone and face-to-face contact.

\section{Linkages and location}

The preceeding discussion has demonstrated that both the upstream and downstream linkages involve significant levels of transactions-intensive interaction between different producers. These characteristics of the local electronics complex are almost certainly interrelated with one another, in the sense that high spatially-dependent transactions costs encourage locational agglomeration and discourage locational dispersal. This is a finding that was strongly to the fore in the parallel study of the aircraft and parts industry of Southern California (Scott and Mattingly, 1989). Moreover, with deepening fragmentation of the local manufacturing system into increasingly specialized sub-sectors of production, thus leading to yet further trans-

Table 7

Simple correlations between purchases and sales patterns of sample electronics establishments in Southern California $(n=61)$

\begin{tabular}{lcc}
\hline \hline & $\begin{array}{c}\text { Percent Purchases } \\
\text { within 15 miles }\end{array}$ & $\begin{array}{c}\text { Percent Purchases } \\
\text { within Southern California }\end{array}$ \\
\hline $\begin{array}{l}\text { Percent customers } \\
\text { within 15 miles }\end{array}$ & $0.49^{* *}$ & $0.23^{*}$ \\
$\begin{array}{l}\text { Percent customers } \\
\text { in Southern California }\end{array}$ & $0.31^{* *}$ & 0.19 \\
\hline \hline
\end{tabular}

*Significant at 0.05 level.

**Significant at 0.01 level. 


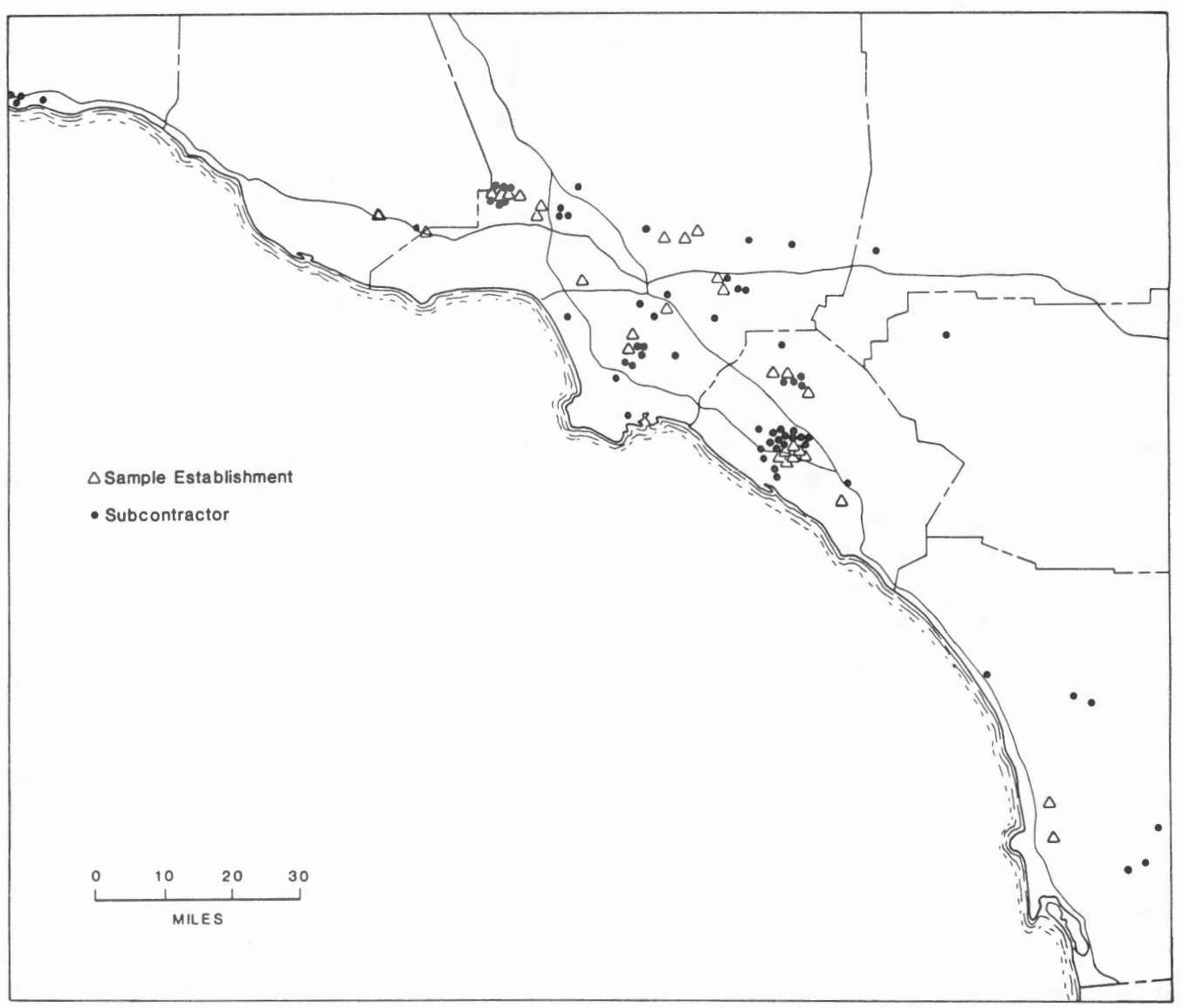

Figure 6. Location of sample electronics establishments and the major subcontract firms to which they put out work.

actional activity, the observed tendency of the entire system to agglomeration within a series of specialized technopoles is reinforced. Within these technopoles, the clustering of small establishments is especially intense.

\section{Conclusion}

We have attempted in the above analysis to provide a reasoned empirical description of the historical unfolding and the current locational structure of the electronicsindus- try of Southern California. The industry has grown since the Second World War to form one of the major high technology industrial complexes in the United States, and together with the aerospace industry with which it is functionally and spatially allied, it constitutes one of the primary engines of the impressive expansion of the Southem Californian economy over the last few decades.

As we have attempted to show above, the peculiar pattern of development and growth of the industry in Southern California can in large part be understand in

Table 8

Putting out activities of sample electronics establishments in Southern California.

Size of establishment (annual sales)

$<\$ 2$ million $\quad>\$ 2$ million

a. Number of respondents

b. Total number of subcontractors mentioned by respondents

c. Subcontractors in Southern California

d. $c$ as a percentage of $b$
18

48

46

$95.8 \%$
15

34

29

$85.3 \%$ 
Table 9

Percentage of time on average allocated to different modes of transacting in the negotiations leading up to a sale of output or subcontract work.

\begin{tabular}{lccccc}
\hline \hline & \multicolumn{2}{c}{ Catalog item sale } & & \multicolumn{2}{c}{ Sale of subcontract work } \\
& $\begin{array}{c}\text { Simple } \\
\text { Average } \\
(\mathrm{n}=53)\end{array}$ & $\begin{array}{c}\text { Weighted } \\
\text { Average } \\
(\mathrm{n}=51)\end{array}$ & & $\begin{array}{c}\text { Simple } \\
\text { Average } \\
(\mathrm{n}=50)\end{array}$ & $\begin{array}{c}\text { Weighted } \\
\text { Average } \\
(\mathrm{n}=47)\end{array}$ \\
\hline Telephone & 58.7 & 48.1 & 38.6 & 26.2 \\
Face-to-face contact & 19.0 & 26.7 & 37.6 & 52.4 \\
Mail & 8.6 & 9.4 & 8.4 & 11.1 \\
Telex/fax & 10.1 & 12.3 & 9.7 & 7.9 \\
Other & 2.5 & 3.5 & 1.6 & 3.1 \\
\hline \hline
\end{tabular}

terms of the extremely high levels of federal defense spending that have been directed over a long period of time to the Southern California high technology industrial complex, together with a series of employment and organizational attributes that have encouraged much specialization and agglomeration of the industry. These attributes involve on the one side, the emergence of large, multifaceted, and rapidly-rotating local labor markets to which firms gain maximal access through mutual locational convergence, and on the other side, a proliferation of localized inter-firm transactional relations binding the entire complex into a functionally integrated system. Recent research (e.g. by Gordon, Dilts, and Kimball 1989) has suggested that locational agglomeration is also encouraged by the increasing tendency of high technology firms, even small ones, to enter into multiple strategic alliances with one another. This is an issue that we have not dealt with in this paper, but that will be taken up explicitly as we begin the tasks of extending the present research program.

Today, the electronics industry in Southern California is spatially organized in a series of dense agglomerated technopoles rooted in the west central and northwestern sections of Los Angeles county as well as in the outer cities of the region. We must not lose sight of the fact that the technopoles of Southern California are also inserted into national and international systems of economic interaction, involving both the active relocation offshore of large standardized units of production (such as assembly plants), and the world-wide search for specialized inputs and markets. They are also buffeted by intensifying foreign competition, especially from Japan and the newly industrializing countries of East and Southeast Asia. One of the major areas for additional research, it seems to us, is the question of the future of the electronics industry in Southem California relative to the growth of high technology industry in the world at large, and the identification of relevant institutional arrangements and policy mechanisms that might enhance itscontinued viability and innovativeness in the local area.

Finally, further analysis of the much-neglected question of labor markets within the electronics industries of Southern California and other expanding high technology industrial regions is needed. Important issues calling urgently for attention include (a) the dynamics of job search, recruitment, training and turnover, (b) labor relations systems and the politics of work in both upper and lower tier labor market segments; and (c) the relationships between the bifurcation of local labor markets and the social reproduction of workers within spatially-segregated communities. The existence of a highly-paid managerial and scientific workforce alongside poorly-paid, predominantly female and ethnic production workers is symptomatic of overall labor market trends within agglomerated high technology manufacturing regions like Southern California. This poses important questions about the wider urban dynamic of the region, as well as about its future trajectory of socio-political development.

\section{References}

Angel, D. (1989) Production, Labor Markets and Location: A Case Study of the US Semiconductor Industry, unpublished Ph.D. dissertation, Department of Geography, University of California, Los Angeles, 1989.

Aviation Week. "The pattern of US defense expansion", Number 55, 24th September, 1951, 14-15.

Fernandez Kelly, M.P. "Economic restructuring in the United States: the case of Hispanic women in the garment and electronics industries of Southern California", a paper presented at the thematic panel on The New International Division of Labor: Implications for Working Women and Working Men, meetings of the American Sociological Association, August, 1987.

Gordon, R., Dilts, A. and Kimball, L.M. "High technology 
innovations and the global milieu: small- and medium-sized enterprises in Silicon Valley", in J-C. Perrin and D. Maillat (eds.) Milieux Innovateurs et Processus d'Innovation dans les Entreprises, Paris, 1989.

Hall, P., and Preston, P. The Carrier Wave: New Information Technology and the Geography of Innovation. 1846-2003, London: Unwin Hyman, 1988.

Hughes Aircraft Company. The History, Culture, and Organization of the Hughes Aircraft Company Los Angeles: Hughes Aircraft Company, Corporate Human Resources, 1986.

Mettler, R.F. The Little Brown Hen that Could: The Growth Story of TRW Inc. New York: The Newcomen Society in North America, publication number 1172, 1982.

Oakey, R. High Technology Small Firms, New York: St. Martin's Press, 1984.
Ramo, S. The Business of Science, New York: Hill and Wang, 1988.

Scott, A. J. Metropolis: From the Division of Labor to Urban Form, Berkeley and Los Angeles: University of California Press, 1988. , and Mattingly, D. J. "The aircraft and parts industry in Southern California: continuity and change from the interWar years to the 1990s",Economic Geography, 65 (1989), 48-71.

, and Paul, A. S. "Industrial development and regional growth in Southem California, 1970 - 1987", in D.J. B. Mitchell and J. Wildhom (eds.) Can Califomia be Competitive and Caring? University of California, Los Angeles, Institute of Industrial Relations, Monograph and Research Series No. 49, 1989, 57-111. 